\title{
A Tale of Two Regimes: Instrumentality and Commons Access
}

\author{
Noah J. Toly \\ University of Delaware
}

Technical developments have profound social and environmental impacts. Both are observed in the implications of regimes of instrumentality for commons access regimes. Establishing social, material, ecological, intellectual, and moral infrastructures, technologies are partly constitutive of commons access and may militate against governance according to principles of ecological justice. This article examines the relationship between regimes of instrumentality and commons access regimes, exploring the effects of bioprospecting on the biodiversity commons.

Keywords: biodiversity; commons; technology; instrumentality; environmental regimes

$\mathrm{E}$ nvironmentalists are, by and large, unaware of Jacques Ellul's importance to the discourse regarding nature-society relations. Although his activism reflected great concern for the natural environment and for what might be described today as environmental justice (Ellul, 1997a, pp. 25-26), few of his many scholarly contributions are solely concerned with ecological questions. Upon closer examination, however, Ellul seems an apt selection, offering one of the most penetrating analyses of technological society from which contemporary environmental crises cannot be divorced and presenting explicit insights into the state of nature in a technological society. ${ }^{1}$

Among Ellul's concerns was the commons. In The Technological Society, Ellul (1964) specifically addressed the enclosure of the commons in France and England:

The movement was accelerated by the application of new agricultural methods. ... The new

Bulletin of Science, Technology \& Society, Vol. 25, No. 1, February 2005, 26-36 DOI: $10.1177 / 0270467604271214$

Copyright @ 2005 Sage Publications

agricultural techniques were plainly so superior that it was not possible to preserve the old "open field" system - the commons, the pastures, and the forests; thus the final blow was dealt to the old organic peasant society. (p. 57)

Ellul understood this enclosure to result from the advance of technique, acknowledging the effects of technique on both environment and society while also suggesting the importance of the commons as a mode of social and ecological relations.

The commons serves not only as an important form of relations but also as a didactic and experimental tool. As Dietz, Dolsak, Ostrom, and Stern (2002) wrote,

The commons provides a tractable and yet important context in which to address [questions of social science]. Just as evolutionary and developmental biology progressed by studying the fruitfly ... we suggest that studies of the commons ... are an ideal test bed for many key questions in the social sciences. (p. 5)

Premised on the idea that the commons serves as well as a tractable and important context within which to address the relationships between technology, environment, and society, this article identifies manners in which technique shapes access to the commons.

Impacts of technique on the commons, however, are manifold, and this diversity guides the analysis offered herein. A potentially useful typology of the implications of technique for the construction of commons access regimes is offered along with an attempt to illustrate the value of this typology through an application to biological diversity.

\section{The Publications}




\section{A Tale of Two Regimes}

A helpful framework for analyzing the impacts of technique on the commons includes an examination of two distinct types of regimes. Intersections between "regimes of instrumentality" (Winner 1986, pp. 5458), and commons access regimes serve as a point of entry for an evaluation that avoids reductionist tendencies in the analysis of the implications of technology. Regimes of instrumentality are partly constitutive of commons access regimes, participating in the construction, valuation, and distribution of ecologies through the establishment of various infrastructures: material, social, ecological, intellectual, and moral. ${ }^{2}$ Each will be examined below.

\section{Commons Access Regimes}

Commons access regimes are the formal and informal rules governing the appropriation and management of common pool resources, which are often described as existing outside the bounds of sovereignty-bound actors, legitimately claimed by multiple stakeholders, basic to life on earth, or immediately supporting the lives and livelihoods of proximate stakeholders. Common pool resources are "accessible to many potential harvesters who can extract marginal personal [or corporate] benefits at a cost that is [relatively] low because all harvesters share it" (Kennedy, 2003, p. 1861). McKean (2000) described common pool resources as "goods that can be kept from potential users only at great cost or with great difficulty but that are subtractable in consumption and can thus disappear" (p. 28). These resources, as well as the regimes that govern access to them, are partly constituted by the material, social, ecological, intellectual, and moral infrastructures created by specific techniques.

A growing literature on the commons finds its recent origins in the 1970s and Garret Hardin's (1998) well-known article, "The Tragedy of the Commons." Hardin's analysis, although insightful, was reductionist, characterizing all commons as subject to the governance of what some describe as an open-access regime in which there are no social mechanisms to limit extractive uses by any given individual or by the group as a whole. As Dietz, Ostrom, and Stern (2003) wrote, "Hardin's oversimplification was twofold: He claimed that only two state-established institutional arrangements - centralized government and private property-could sustain commons over the long run, and he presumed that resource users were trapped in a commons dilemma, unable to create solutions" (p. 1907). Pretty (2003) described Hardin's false dichotomy: If we are to avoid the tragedy of the commons, we must "engage in mutual coercion mutually agreed upon, or press ahead with enclosure and privatization to increase the likelihood that resources will be more carefully managed" (Dietz et al., 2003, p. 1912). Hardin (1994) himself has acknowledged the reductionism of his analysis in more recent writings. Furthermore, as one among many types of commons access regimes, truly open access is relatively unusual and would seem to presume the neoliberal ideal of rational materialist egoism. Despite these faults, Hardin's analysis has greatly influenced our understanding of human ecology.

Although flawed, Hardin's evaluation pointed to the potentially conflictual conditions of commons access. Indeed, the commons and access to them are subject to what Mouffe (1999) has described as "the political" or "the dimension of antagonism that is inherent in all human society, antagonism that can take many different forms and can emerge in diverse social relations" (p. 754). Arrangements by which this conflict is mediated or legitimated are described by Mouffe as "politics," consisting of more or less robust combinations of discourses, institutions, and practices that "seek to establish a certain order and to organize human coexistence in conditions that are always potentially conflictual" (p. 754). In the midst of potential antagonisms attendant to the commons, these discourses, institutions, and practices have been invaluable in maintaining ecological integrity for centuries and at the same time demonstrate a notinconsiderable range of possibilities for commons governance- - "arrangements for the cooperative (shared, joint, collective) use, management, and sometimes ownership of natural resources" (McKean, 2000 , p. 27). Indeed, seemingly innumerable commons access models have existed for ages. As Dietz et al. (2003) wrote, "Locally evolved institutional arrangements governed by stable communities and buffered from outside forces have sustained resources successfully for centuries" (p. 1907) and have proved effective systems of commons access in some cases until the development of new techniques of the sort referenced by Ellul (1964, p. 57).

Although most literature regarding commons access regimes focuses on the management of common resources through privatization, a portion of the literature reflects on this privatization as an ecologically un- 
sustainable and socially inequitable commodification of common resources and access to them, promoting instead a commons approach to resource governance consistent with the principles of ecological justice. As Byrne and Glover (2002) wrote,

In contrast to Hardin's argument that the commons are a source of social and environmental "tragedy" . . . commons style governance can produce solutions to the causes of degradation, most notably in the cases of such global commons as biodiversity and climate. (p. 13)

Commons-style governance of the sort advocated by Byrne and Glover emerges as a legitimate model for commons access, especially with the rejection of ahistorical economistic reductionism so prevalent in the "global fad" of privatization (McKean, 2000, p. 27). A truly commons approach to common pool resources may promote both equity and sustainability where privatization may fail to achieve one or both of these objectives. As McKean (2000) wrote, "Far from being quaint relics of a hunter-gatherer or medieval past, common property regimes may be what we need to create for the management of common pool resources" (p. 35).

Commons access regimes, of one type or another, are of paramount importance to the maintenance of ecological integrity and prove instrumental in the construction of social relations, whether equitable or inequitable. As noted by Ellul, though, commons access regimes of whatever sort are shaped in large part by technologies, some of which may preclude a commons approach to ecological justice. This interaction is the intersection between commons access regimes and regimes of instrumentality.

\section{Regimes of Instrumentality}

Regimes of instrumentality are, according to Winner (1986), the "material and social infrastructures specific technologies create for our life's activities" (p. 55). Winner, one of Ellul's most sympathetic critics and drawing to a large extent on Ellul's considerable corpus, suggested that the collective impact of these regimes is a technical constitution "that stands parallel to and occasionally overlaps the constitution of political society as such" (p. 55). In this regard, technique stands parallel to the discourses, practices, and institutions described by Mouffe (1999), mediating or legitimating particular social ends. Expanding
Winner's concept, one might suggest that regimes of instrumentality would include the infrastructures created by technique, in the Ellulian sense (i.e., economic technique), in which case the technical constitution to which Winner referred might demonstrate considerably greater overlap with the explicitly political, even tending to subsume the political in some regard.

An Ellulian expansion of Winner's framework also requires the inclusion of infrastructures beyond those of the material and the social, including the ecological, the intellectual, and the moral. For example, a large body of research finds the political to be constitutive of the ecological as well as the material and social, suggesting that regimes of instrumentality are political ecological forces. Specific techniques and technologies determine the manners in which we interact with nature and, in many cases, modify or even undermine the integrity of ecological systems and processes. In this way, technique may indirectly manipulate commons access regimes through the transformation of the common pool resources to which they govern access. This may, in fact, be a fundamental interaction between the two regimes, because the construction of particular ecologies entails both environmental and social implications, constituting an ecological infrastructure as fundamental to the impacts of technique as the material and social infrastructures identified by Winner (1986).

Particular techniques or technologies also establish intellectual infrastructures through the advance of a particular way of thinking about a given common pool resource. The development of a specific technology or the subjection of the commons or a commons access regime to a technique or set of techniques is partly determinant of the manner in which we think about these resources and access to them. For example, privatization of the type advanced by many emergent policies is an economic technique that suggests thinking about a resource as a discrete commodity, the use of which has limited implications for anything or anyone other than the owner and the primary value of which is in exchange. Plumwood (2002) has described this as the "ethics of commodification" (pp. 143-166), that is, an ethics by which particular techniques or technologies serve to rationalize access to commons resources and to make access consistent with other governing logics and infrastructures, including those of the global political economy.

Furthermore, and quite related to the foundation of this intellectual infrastructure, technique establishes a 
particular moral infrastructure, which Ellul (1997b) described as "realistic politics":

a morality in which there is no longer good and evil, just and unjust, legal and illegal, right and wrong. This is a morality of what succeeds and does not succeed, of what is useful and what is not. And this is truly a morality that today conditions all our life, and that is why it seems absolutely ridiculous ... to discuss doctrines or ideas. (p. 60)

This morality of the fact establishes the parameters of right action regarding commons access. "The fact," wrote Ellul (1997b), "is established, is seen, or is thought to be seen; it cannot be debated. No opinion can stand up in the face of the fact. There is not guide or truth; the fact is justified by itself and is sufficient in itself. Fact replaces truth" (p. 54). In this politics, "it is no longer necessary to deliver judgment, the facts take charge, and we need only to follow the facts" (Ellul, 1997b, p. 60); and what matters "is no longer the right or the true or the beautiful, but the fact" (p. 57). Although ecological justice is a highly situational ethic, this moral imperative is subject to abstraction and efficiency and given to governance by the market (which, as Polanyi, 1944, asserted, is an attempt to extract the economic from all social and natural context), in that the primacy of the economic over the political is a fundamental element of realistic politics (Ellul, 1997b, p. 56).

And it is a moral imperative. As Ellul (1997b) wrote, "True realistic politics is like a boxer who knocks out his adversary: No discussion" (p. 58). Ellul has described the fact as "a veritable god" (p. 57), and Sachs (1999) has articulated the religious tenor of its moral infrastructure, describing it as "the gospel of global efficiency" (pp. 47-55). This "good news" militates against governance according to the principles of ecological justice-environmental sustainability and social equity. Indeed, ecological justice and the "morality of the fact" are mutually subversive: "Efficiency is a fact and justice a slogan" (Ellul, 1964, p. 282).

Participating in the construction, valuation, and distribution of ecologies, the infrastructures described above, material, social, ecological, intellectual, and moral sometimes coincide in the "production of unequal nature" (Byrne, Glover, \& Martinez, 2002). For this reason, the scope of a technique's potential to constitute commons access regimes, for good or for ill, merits a close examination of the developments wrought by technologies as they are introduced. New techniques should be interrogated for their potential infrastructural implications and the consistency of those implications with particular values and ethics.

\section{The Biodiversity Crisis}

Although this infrastructural typology provides a useful tool in an examination of the intersection between regimes of instrumentality and commons access regimes, these types are certainly not clearly disentangled in reality. Indeed, the social, material, ecological, intellectual, and moral are co-constitutive elements of a metainfrastructure that partly composes commons access. For this reason, a close examination of a particular instance is especially helpful, and the biological diversity commons provides a practical case for analysis. Biodiversity is often advanced as a model common pool resource, and multiscalar access regimes have shaped its use for centuries. Emerging techniques subject biodiversity to new imperatives and rationalities, forming the social, material, ecological, intellectual, and moral infrastructures that are partly constitutive of new access regimes at various scales.

A multitude of definitions for biodiversity exist. One of the most careful, in its specificity and inclusiveness, is offered by Sandlund, Hindar, and Brown (1992), who described it as "the structural and functional variety of life forms at genetic, population, community, and ecosystem levels" (p. 1). This multitiered diversity is a lynchpin of ecological integrity and a precondition for human life and society. It is the source of "all of our cultivated plants and domesticated animals, animal pollinators, biological agents for pest and disease control, and thousands of pharmaceuticals" (DeWitt, 2003, p. 358). Biodiversity is also a foundational element of a great range of

ecological services provided by the biosphere, including soil formation and fertility renewal, reducing flood peaks and increasing drought flows of streams, processing oxygen and carbon dioxide, moderating local climates, and maintaining a wide array of biogeochemical cycles (for example, phosphorous cycle and nitrogen cycle). (DeWitt, 2003, p. 358)

High levels of biodiversity contribute to greater biological productivity and ecosystem function, more reliable ecosystem services, and increased efficiency 
with which resources, both from soil and atmosphere, are captured (Tilman, 2000). Mooney et al. (1995) noted that biodiversity is central to

maintenance of the gaseous quality of the atmosphere (which in turn helps to regulate climate); amelioration of the weather; control of the hydrological cycle (including reduction of the probability of serious floods and droughts); protection of coastal zones by generating and conserving coral reef and sand dune systems; generation and conservation of fertile soils, which are essential to agriculture and forestry; dispersal and breakdown of wastes and cycling of nutrients; control of the vast majority of potential crop pests and vectors of disease; pollination of many crops, and direct provision of food from sea and land; and the maintenance of a vast "genetic library" from which Homo sapiens has already extracted the very basis of civilization in the form of crops, domestic animals, medicines and industrial products. (pp. 282-283)

Biodiversity is clearly basic to life on earth.

Although the natural import of biodiversity cannot be overstated, it also carries a great deal of social significance. Although conventional economic analysis dominates the discourse regarding the social significance of biodiversity, ethical, moral, spiritual, and gender-related concerns also mark the debate (Ayres, 2003; MacDonald \& Nierenberg, 2003; Maffi, 1999; Perrings et al., 1995; Posey, 1999; Rocheleau et al., 2001; Rocheleau \& Ross, 1997). Furthermore, biodiversity serves as an anchor for ecologically mediated identities and an element of cultural and political discourse among social movements of various local communities (Escobar, 1996, 1998, 1999).

However, in spite of its obvious natural and social importance, biodiversity is declining at record levels. As DeWitt (2003) wrote,

Despite our knowledge of its critical importance to the health and integrity of the biosphere, biodiversity is seriously threatened and is being reduced through habitat destruction, clearing of land and forests, putting toxic materials into global circulations, introducing exotic species, and changing climate. (p. 358)

Recent research demonstrates the changing profile of causes of biodiversity loss. The top four current causes are (a) climate change, (b) nutrient runoff, (c) land use change, and (d) invasive species (Chapin et al., 2000, p. 234). This profile is likely to have changed significantly by 2100 ; by the beginning of the 22 nd century, the top five causes are projected to be (a) land use change, (b) climate change, (c) nitrogen deposition/ nutrient runoff, (d) invasive species, and (e) increased concentrations of atmospheric $\mathrm{CO}_{2}$ (Chapin et al., 2000, p. 234).

The relatively recent emergence of biodiversity as a scientific concept and the challenges of global and regional taxonomic surveys account for particular limitations to and uncertainties in the scientific discourse. As DeWitt (2003) wrote, "Assessment of biodiversity is complicated by the fact that we have only begun to identify the biological species of the world" (p. 359). This recent emergence also accounts for a relatively limited number of theories to explain declining numbers of species. Indeed, estimates of global biodiversity loss are largely based on extrapolations from either the "equilibrium theory of island biogeography" or "metapopulation theory" (Levins, 1970; MacArthur \& Wilson, 1967; Van Dyke, 2003, pp. 113143). These theories stipulate population sizes and levels of specie diversity supported by habitats of various sizes and levels of isolation and account only for biodiversity loss due to land use change and habitat fragmentation, treating other causes-climate change, introduction of toxic and hazardous materials, increasing concentrations of atmospheric $\mathrm{CO}_{2}$-as peripheral. We can expect, therefore, that approximations of current biodiversity loss underestimate actual levels. Furthermore, due to a lag effect, Pimm and Raven (2000) suggested that "at current rates of habitat destruction, the peak of extinctions might not occur for decades" (p. 844), projecting that losses will crest at almost 500,000 species between 2060 and 2070.

This magnitude of biodiversity loss implies significant natural and social consequences. Biophysical consequences at the ecosystemic level include a decline in specific richness and evenness, changes in specific composition and interaction, and decreased resilience and resistance to invasive species (Chapin et al., 2000, pp. 234-239). The potential decline in ecosystem services offered is also dramatic, particularly where positive feedbacks are associated with especially large losses (Barbault et al., 1995; Mooney et al., 1995). Declining ecosystem services may have remarkable social consequences. For example, the loss 
of carbon sequestration capacity and watershed protection may have significant global economic costs.

Other significant social consequences are also possible and might extend to the aesthetic, cultural, intellectual, linguistic, and spiritual realms (Chapin et al., 2000; Maffi, 1999; Posey, 1999). Loss of culturally relevant species or ecosystems could prove a dramatic turning point in identity politics, and large-scale losses of biodiversity might weaken the capacity for knowledge-building exercises in the sciences and erode the economic potential of various ecosystems and regions. For some communities, biodiversitydependent ecosystem integrity is a matter of life or death. Communities heavily dependent on marine resources, for example, face potentially devastating consequences of the declining aquatic biodiversity due to the bleaching of coral reefs.

\section{Bioprospecting and the Biodiversity Crisis}

Early reaction to the loss of biological diversity included an emphasis on the establishment of strictly protected parks and wilderness areas. These areas were intended to exclude most human activity and yet permit the flourishing of nature within the boundaries and the flourishing of society, based on the conquest of nature, outside of those boundaries. In spite of these efforts, however, biodiversity continues to suffer an immense assault on its magnitude, in part because attention to habitat preservation, although laudable, does not address other leading causes of extinction. For example, the effects of climate change cannot be excluded from parks and reserves. The reach of social intervention in natural processes extends across these boundaries.

Despite the ongoing extinction crisis, the past two decades have witnessed small advances in the fight to secure a biodiverse future. Nevertheless, failures and fundamental flaws in conservation policy and practice have effected remarkable changes in the political economic response to the crisis. Conservation efforts that once focused on an enforcement of exclusion of society from nature have recently developed a preoccupation with the integration of ecological values and particular social, especially economic, values for the protection of biodiversity. New techniques have recently emerged that have great impacts on the biodiversity commons access regime. Bioprospecting is a material technique with multiple infrastructural implications, whereas a regime of international intellectual property (which cannot be divorced from prospecting efforts) is a nonmaterial technique with likewise multiple infrastructural implications.

Bioprospecting has been defined as "the systematic search for genes, natural compounds, designs, and whole organisms in wild life with a potential for product development by biological observation and biophysical, biochemical, and genetic methods, without disruption to nature" (Mateo, Nader, \& Tamayo, 2001, p. 471). This definition intentionally comprehends both traditional and modern bioprospecting. Where product development is primarily concerned with use values, bioprospecting is not new. Traditional agricultural and medicinal developments reflect even ancient bioprospecting efforts somewhat continuous with contemporary bioprospecting.

Although the definition offered above is reasonable, a more specifically modern definition was presented by Reid et al. (1993) when they described bioprospecting as "the exploration of biodiversity for commercially valuable genetic and biochemical resources" (p. 1). Still another is proposed by Mateo et al. (2001), who suggested that "bioprospecting has been used to indicate the search for new sources of chemical compounds, genes, proteins, microorganisms, and other products that have economic potential and that can be found in the world's diversity of plants, animals, and microorganisms" (p. 480). Both of these definitions suggest a more typically modern concern for exchange value. The ends of bioprospecting have been modified somewhat in prioritizing exchange over use, reflecting a significant departure from traditional bioprospecting. This discontinuity, among others, lends a problematic nature to the modern enterprise.

A second discontinuity is one of means. Traditional bioprospecting certainly required significant technical expertise. Both knowledge of the medicinal qualities of particular wild and domestic flora and fauna and practical expertise in plant and animal breeding anticipate to some degree contemporary pharmaceutical and agronomical techniques. Continuity is also evident in evaluation of "traditional uses of plants, animals, and microorganisms" by bioprospectors, whereas discontinuity of means is evidenced in their employment of "random sampling, or, in the biorational approach, systematic analysis of biological phenomena" (Mateo et al., 2001, p. 473; see also Tamayo, Nader, \& Sittenfeld, 1997). Both chemical and genetic prospecting employ these modern techniques. 
Chemical prospecting is most relevant to pharmaceutical applications and has its greatest continuities (and its most significant discontinuities) with traditional medicinal uses of biological resources. Eisner $(1989,1992)$ is generally credited with its first articulation, developing the concept as "a collaborative effort among conservationists, scientists, the pharmaceutical industry, and biodiversity-rich countries to develop products from biodiversity and to generate income for its conservation" (Mateo et al., 2001, p. 474). Although its means include the identification of use values, its purpose is the identification and exploitation of exchange values.

Although the medicinal benefits of gene prospecting are still emerging, this mode is most continuous with traditional plant and animal breeding. "The selection of various phenotypes (and thus genes)," wrote Mateo et al. (2001), "has been used traditionally for plant and animal breeding, and modern gene technology offers many new opportunities" (p. 476). Defining gene prospecting as the search for "enzymes with new substrate specificity and physicochemical characteristics," the authors suggested that new "gene technology allows their production in nearly unlimited amounts at low cost" (Mateo et al., 2001, p. 476). Here bioprospecting is linked with another emergent form, biotechnology. Biotechnology and the international regime of intellectual property rights, embodied in the Trade Related Aspects of Intellectual Property (TRIPs) protocol, are both intimately tied to bioprospecting.

The international regime of intellectual property rights represents both an unacknowledged continuity and a significant discontinuity with traditional biological diversity prospecting. Medicinal and agricultural applications of modern bioprospecting rely heavily on developments in traditional ecological knowledge. Many medicinal applications originate with the observation of traditional practices. As for agricultural applications, as Mateo et al. (2001) suggested, "Our world would be a totally different place today if crops and domestic animals had not been moved from their centers of origins and domestication to other parts of the world" (p. 480). Yet the traditional heritage of both crops and medicines is often unacknowledged. Bioprospecting and the TRIPs protocol are dependent on the concept of novelty in national and international patent law. Although bioprospectors argue the novelty of a structure or application derived by modern techniques, many dispute that implication of discontinuity, suggesting the continuity with traditional knowledge and practice. Furthermore, bioprospecting's relationship with the TRIPs regime represents a significant departure from traditional modes of knowledge. The international regime of intellectual property rights achieves the privatization and commodification of knowledge, contrary to a strong, if not always present, community approach to knowledge generation, appropriation, and management in traditional societies, both past and present.

The conservation mechanism of bioprospecting is premised on the principle of benefit sharing, either direct or indirect. Bioprospecting-related products in fields such as pharmaceuticals, agrochemistry, enzymes, phytopharmaceuticals, seeds, and natural cosmetics represented more than U.S. $\$ 147$ billion annually in 1998 (Mateo et al., 2001, p. 479). Mateo et al. (2001) wrote,

The value of sources of unique biological materials and products was estimated as U.S. \$79 per hectare of forest per year. The value of yet undiscovered pharmaceuticals in tropical forests was estimated at U.S. \$3-4 billion for a private pharmaceutical company, and as much as U.S. \$147 billion ... to global society. (p. 480)

An effective contribution to conservation is predicated on these markets: "to be effective as an element of conservation, bioprospecting must contribute to the generation of wealth through R\&D and must also alleviate poverty in biodiversity-rich regions" (Mateo et al., 2001, p. 480). Indeed, Mateo et al. (2001) wrote that "communities inside or bordering protected areas must participate in conservation and must benefit from bioprospecting activities in their own regions" (p. 480). This, of course, implies the involvement of local stakeholders at the community level. Possible involvements noted by Mateo et al. include "growing, grading, and packing of medicinal plants; cultivation of new ornamental plants; domestication, cultivation, and primary production of biopesticides; cultivation and processing of aromatic teas; and exploration and evaluation of local landraces with resistant genes of interest" (p. 480). In Costa Rica, bioprospectors have garnered the support of some local communities through training and employment as parataxonomists supporting a national biodiversity inventory.

Bioprospecting undertaken apart from a benefitsharing plan is described by many as biopiracy - the 
uncompensated appropriation of knowledge and resources. However, many have also described as biopiracy both the unacknowledged heritage of agricultural products and the appropriation of indigenous and peasant knowledge of medicinal applications of wild species, suggesting that biopiracy is not simply a matter of compensation but rather also of involuntary participation and unacknowledged legacy. Furthermore, many suggest that bioprospecting-related intellectual property rights (IPRs) effectively preclude the indigenous and peasant uses on which many biodiversityrelated patents are based. Shiva (1997) related biopiracy to the question of the biodiversity commons, writing,

IPRs exploit knowledge for profit by excluding others from its use during the lifetime of the patent. Since IPRs are often based on local knowledge and on tinkering with biodiversity that has hitherto been in the commons, they amount to an intellectual and material enclosure. Consequently, people lose access to the knowledge and resources vital to their survival and creativity, and to the conservation of cultural and biological diversity. (pp. 68-69)

Shiva described bioprospecting as the enclosure of a material commons, preventing access to the diversity of biological resources, themselves, and the enclosure of an intellectual commons, precluding the application of knowledge to ends other than the accumulation of capital through the privatization of knowledge.

This enclosure issues from the social, material, ecological, intellectual, and moral infrastructures constructed by bioprospecting. Social and material infrastructures are generated by the technology of bioprospecting as much as by its technique. Laboratory equipment and scientific training divide the haves from the have-nots. As Escobar (1999) noted, "From tropical rain forests to advanced biotechnology laboratories, the cultural and biological resources for collectively inventing natures and identities are very unevenly distributed" (p. 2).

This capacity for the collective invention of natures is evident in the problematic ecological infrastructure of bioprospecting. Significant financial resources are devoted to the conservation of ecosystems with demonstrated or anticipated commercially valuable resources to the exclusion of those without. With few notable exceptions, the majority of bioprospecting arrangements involve tropical ecosystems in Latin
America, Asia, and Africa. This uneven development of bioprospecting initiatives is not the only problematic aspect of its ecological infrastructure. As Mateo et al. (2001) noted, "In contrast to our forest-dwelling bioprospecting ancestors, we no longer need to use the biological original to create a finished product" (p. 472). Synthetic products with the commercially valuable traits of their natural counterparts, coupled with emergent genetic, chemical, and information technologies, enable ex situ conservation that may radically transform ecological infrastructures. Both the selective deployment of bioprospecting efforts and the capacity for ex situ conservation potentiate a technicized ecology with significant implications for commons access.

Bioprospecting's intellectual infrastructure likewise holds important consequences for commons access. Bioprospecting encourages thinking about the diversity of life as potentially commercially valuable biological resources, the genetic and chemical traits of which are to be isolated in search of maximum exchange value. Escobar (1996) noted that the intellectual infrastructure of bioprospecting is one in which "even the genes of living species are seen in terms of production and profitability" (p. 47), promulgating "certain views of nature and society in terms of production and efficiency, not of respect and the common good" (p. 53). This perspective is intimately tied to the nonmaterial technique of privatization embedded in the international regime of intellectual property rights. Knowledge of both agricultural and medicinal applications of biological resources is privatized in an enclosure of the intellectual commons that undergirds the enclosure of the biological commons.

Finally, the moral infrastructure of bioprospecting and privatized intellectual property is that of realistic politics. A moral imperative- know, use, saveaccompanies emergent biodiversity conservation mechanisms. This triad of conservation principles mandates the use of biological resources for the purposes of sustainable development. Seemingly open to multiple purposes and use values, the vast majority of its applications-bioprospecting among themassume the primacy of exchange values. Resources for conservation are to be allocated efficiently.

\section{Conclusion}

The material, social, ecological, and moral infrastructures established by bioprospecting and related techniques are party to the formation of a commons ac- 
cess regime that promotes the capitalization of nature, unequal access to natural resources, and the construction of privileged ecologies (Byrne et al., 2002). These material and nonmaterial techniques establish a multifaceted metainfrastructure that in large measure constitutes a regime of access to the biodiversity commons. As Gorg and Brand (2000) argued,

While in the public domain the predominant opinion is that this issue is about measures that can stop or slow down the loss of biological diversity, the international agreements regulating this field must be regarded rather as establishing a regime to regulate the rights of access to, and more or less exclusive rights of disposition of, biological diversity. (p. 372).

Many present this enclosure as a challenge to social equity (see Cox, 2000; Cunningham \& Cunningham, 2000; Laird, Cunningham, \& Lisinge, 2000; Parry, 2000).

Bioprospecting is a challenge not only to social equity but to nature itself. It establishes an artificial diversity contrary to the diversity of prediscursive biophysical realities. As Ellul (1964) wrote, "Technique is opposed to nature," elaborating,

The world that is being created by the accumulation of technical means is an artificial world and hence radically different from the natural world. It destroys, eliminates, or subordinates the natural world, and does not allow this world to restore itself or even to enter into a symbiotic relation with it. The two worlds obey different imperatives, different directives, and different laws which have nothing in common. Just as hydroelectric installations take waterfalls and lead them into conduits, so the technical milieu absorbs the natural. We are rapidly approaching the time when there will be no natural environment at all. When we succeed in producing artificial aurorae boreales, night will disappear and perpetual day will reign over the planet. (p. 79)

Bioprospecting signifies the potential for such artifice, undermining both social and natural ends.

In the face of such subversion, contemporary environmental crises demand a response that addresses both social and environmental concerns in a fair manner. Indeed, they require an infrastructure of consid- erable difference from that of technique. A moral infrastructure of ecological justice must guide the establishment of material, social, ecological, and intellectual infrastructures as well as the construction, valuation, and distribution of ecologies.

\section{Notes}

1. See, for example, Ellul's comments on two questions of ecological justice: nuclear waste (Ellul, 1964, p. 109) and the pollution of the Arcachon basin in the French region of Aquitaine (Ellul, 1990, p. 299). See also two theological contributions (Ellul, 1984a, 1984b).

2. Winner (1986, p. 55) suggested that regimes of instrumentality consist of the material and social infrastructures created by particular technologies. I would like to add that those same technologies, as well as "technique" in the Ellulian (e.g., Ellul, 1964) sense, establish ecological, intellectual, and moral infrastructures. Social relations, built landscapes, natural landscapes, intellectual frameworks, and moral imperatives are all within the domain of the technical impacts on commons access regimes and will be discussed at length below.

\section{References}

Ayres, E. (2003, March/April). Mapping the nature of diversity: A landmark project reveals a remarkable correspondence between indigenous land use and the survival of natural areas. World Watch, pp. 30-32.

Barbault, R., Sastrapradja, S., Hindar, K., Sepkoski, J. J., Slatkin, M., Michalakis, Y., et al. (1995). Generation, maintenance, and loss of biodiversity. In V. H. Heywood (Ed.), Global biodiversity assessment (pp. 193-274). Cambridge, UK: Cambridge University Press.

Byrne, J., \& Glover, L. (2002). A common future or towards a future commons: Globalization and sustainable development since UNCED. International Review for Environmental Strategies, 3(1), 5-25.

Byrne, J., Glover, L., \& Martinez, C. (2002). The production of unequal nature. In J. Byrne, L. Glover, \& C. Martinez (Eds.), Environmental justice: Discourses in international political economy (Vol. 8, pp. 230-256). New Brunswick, NJ: Transaction.

Chapin III, F. S., Zavaleta, E. S., Eviner, V. T., Naylor, R. L., Vitousek, P. M., Reynolds, H. L., et al. (2000). Consequences of changing biodiversity. Nature, 405, 234-242.

Cox, P. A. (2000). A tale of two villages: Culture, conservation, and ecocolonialism in Samoa. In C. Zerner (Ed.), People, plants, and justice: The politics of nature conservation (pp. 330-344). New York: Columbia University Press.

Cunningham, A. B., \& Cunningham, M. (2000). Profits, prunus, and the prostate: International trade in tropical bark. In C. Zerner (Ed.), People, plants, and justice: The politics of nature conservation (pp. 309-329). New York: Columbia University Press.

DeWitt, C. B. (2003). Biogeographic and trophic restructuring of the biosphere: The state of the Earth under human domination. Christian Scholar's Review, 32(4), 347-364. 
Dietz, T., Dolsak, N., Ostrom, E., \& Stern, P. C. (2002). The drama of the commons. In E. Ostrom, T. Dietz, N. Dolsak, P. C. Stern, S. Stonich, \& E. U. Weber (Eds.), The drama of the commons (pp. 3-35). Washington, DC: National Academy Press.

Dietz, T., Ostrom, E., \& Stern, P. C. (2003). The struggle to govern the commons. Science, 302, 1907-1912.

Eisner, T. (1989). Prospecting for nature's chemical riches. Issues in Science and Technology, 6(2), 31-34.

Eisner, T. (1992). Chemical prospecting: A proposal for action. In F. H. Bormann \& S. R. Kellert (Eds.), Ecology, economics, and ethics: The broken circle (pp. 196-202). New Haven, CT: Yale University Press.

Ellul, J. (1964). The technological society (J. Wilkinson, Trans.). New York: Vintage.

Ellul, J. (1984a). The relation of man to the creation according to the Bible. In C. Mitcham \& J. Grote (Eds.), Theology and technology: Essays in Christian analysis and exegesis (pp. 139156). Lanham, MD: University Press of America.

Ellul, J. (1984b). Technique and the opening chapters of Genesis. In C. Mitcham \& J. Grote (Eds.), Theology and technology: Essays in Christian analysis and exegesis (pp. 123-138). Lanham, MD: University Press of America.

Ellul, J. (1990). The technological bluff (G. Bromiley, Trans.). Grand Rapids, MI: Wm. B. Eerdmans.

Ellul, J. (1997a). Perspectives on our age: Jacques Ellul speaks on his life and work. Concord, ON: House of Anansi Press.

Ellul, J. (1997b). Political realism (problems of civilization III) (M. Dawn, Trans.). In M. Dawn (Ed.), Sources and trajectories: Eight early articles by Jacques Ellul that set the stage (pp. 49-91). Grand Rapids, MI: Wm. B. Eerdmans.

Escobar, A. (1996). Constructing nature: Elements for a poststructural political ecology. In R. Peet \& M. Watts (Eds.), Liberation ecologies: Environment, development, social movements (pp. 46-68). New York: Routledge.

Escobar, A. (1998). Whose knowledge, whose nature? Biodiversity, conservation, and the political ecology of social movements. Journal of Political Ecology, 5, 53-82.

Escobar, A. (1999). After nature: Steps to an antiessentialist political ecology. Current Anthropology, 40(1), 1-30.

Gorg, C., \& Brand, U. (2000). Global environmental politics and competition between nation-states: On the regulation of biological diversity. Review of International Political Economy, 7(3), 371-398.

Hardin, G. (1994). The tragedy of the unmanaged commons. Trends in Ecology and Evolution, 9, 199.

Hardin, G. (1998). The tragedy of the commons. In J. S. Dryzek \& D. Schlosberg (Eds.), Debating the Earth: The environmental politics reader (pp. 23-34). Oxford, UK: Oxford University Press.

Kennedy, D. (2003). Sustainability and the commons. Science, 302, 1861.

Laird, S. A., Cunningham, A. B., \& Lisinge, E. (2000). One in ten thousand? The Cameroon case of Ancistrocladus korupensis. In C. Zerner (Ed.), People, plants, and justice: The politics of nature conservation (pp. 345 - 373). New York: Columbia University Press.

Levins, R. (1970). Extinction. In M. Gesternhaber (Ed.), Some mathematical problems in biology (pp. 77-107). Providence, RI: American Mathematical Society.
MacArthur, R. H., \& Wilson, E. O. (1967). The theory of island biogeography. Princeton, NJ: Princeton University Press.

MacDonald, M., \& Nierenberg, D. (2003). Linking population, women, and biodiversity. In L. Starke (Ed.), State of the world: 2003 (pp. 38-61). New York: Norton.

Maffi, L. (1999). Linguistic diversity. In D. A. Posey (Ed.), Cultural and spiritual values of biodiversity: A complementary contribution to the global biodiversity assessment (pp. 19-56). London: Intermediate Technology Publications.

Mateo, N., Nader, W., \& Tamayo, G. (2001). Bioprospecting. In Encyclopedia of biodiversity (Vol. 1, pp. 471-488). San Diego, CA: Academic Press.

McKean, M. A. (2000). Common property: What is it, what is it good for, and what makes it work? In C. C. Gibson, M. A. McKean, \& E. Ostrom (Eds.), People and forests: Communities, institutions, and governance (pp. 27-55). Cambridge, MA: MIT Press.

Mooney, H. A., Lubchenco, J., Dirzo, R., Sala, O. E., Cushman, J. H., Janetos, A. C., et al. (1995). Biodiversity and ecosystem functioning: Basic principles. In V. H. Heywood (Ed.), Global biodiversity assessment (pp. 275-325). Cambridge, UK: Cambridge University Press.

Mouffe, C. (1999). Deliberative democracy or agonistic pluralism. Social Research, 66(3), 745-759.

Parry, B. (2000). The fate of collections: Social justice and the annexation of plant genetic resources. In C. Zerner (Ed.), People, plants, and justice: The politics of nature conservation (pp. 374-402). New York: Columbia University Press.

Perrings, C., Barbier, E. B., Brown, G., Dalmazzone, S., Folke, C., Gadgil, M., et al. (1995). The economic value of biodiversity. In V. H. Heywood (Ed.), Global biodiversity assessment (pp. 823914). Cambridge, UK: Cambridge University Press.

Pimm, S. L., \& Raven, P. (2000). Extinction by numbers. Nature, $403,843-845$.

Plumwood, V. (2002). Environmental culture: The ecological crisis of reason. New York: Routledge.

Polanyi, K. (1944). The great transformation: The political and economic origins of our time. Boston: Beacon.

Posey, D. A. (Ed.). (1999). Cultural and spiritual values of biodiversity: A complementary contribution to the global biodiversity assessment. London: Intermediate Technology Publications.

Pretty, J. (2003). Social capital and the collective management of resources. Science, 302, 1912-1914.

Reid, W. V., Laird, S. A., Gamez, R., Sittenfeld, A., Janzen, D. H., Gollin, M. A., et al. (1993). A new lease on life. In W. V. Reid, S. A. Laird, C. A. Meyer, R. Gamez, A. Sittenfeld, D. H. Janzen, et al. (Eds.), Biodiversity prospecting: Using genetic resources for sustainable development (pp. 1-52). Washington, DC: World Resources Institute.

Rocheleau, D., \& Ross, L. (1997). Women, men, and trees: Gender, power, and property in forest and agrarian landscapes. World Development, 25(8), 1351-1371.

Rocheleau, D., Ross, L., Morrobel, J., Malaret, L., Hernandez, R., \& Kominiak, T. (2001). Complex communities and emergent ecologies in the regional agroforest of Zambrana-Chacuey, Dominican Republic. Ecumene, 8(4), 465-492.

Sachs, W. (1999). Planet dialectics: Explorations in environment and development. New York: Zed Books. 
Sandlund, O. T., Hindar, K., \& Brown, A. H. T. (1992). Conservation of biodiversity for sustainable development. Oslo, Norway: Scandinavian University Press.

Shiva, V. (1997). Biopiracy: The plunder of nature and knowledge. Boston: South End Press.

Tamayo, G., Nader, W. F., \& Sittenfeld, A. (1997). Biodiversity for bioindustries. In J. A. Callow, B. V. Ford-Lloyd, \& H. J. Newbury (Eds.), Biotechnology and plant genetic resources (pp. 255-280). Wallingford, UK: CAB International.
Tilman, D. (2000). Causes, consequences, and ethics of biodiversity. Nature, 405, 208-211.

Van Dyke, F. (2003). Conservation biology: Foundations, concepts, applications. New York: McGraw-Hill Higher Education.

Winner, L. (1986). The whale and the reactor. Chicago: University of Chicago Press.

Noah J. Toly is a research associate in the Center for Energy and Environmental Policy at the University of Delaware. 